
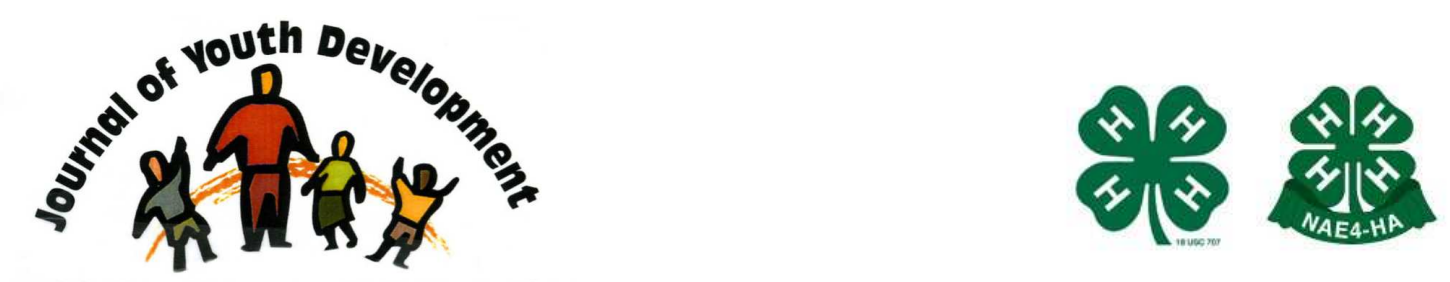

Bridging Research \& Practice

\title{
Locating, Analyzing and Making Available a Century of 4-H Research Studies, 1911-2011
}

\author{
Jan Scholl \\ Penn State University \\ jscholl@psu.edu
}

Amy Paster

Penn State University 


\title{
JOURNAL OF YOUTH DEVELOPMENT \\ bridging research and practice

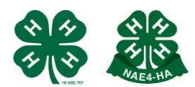

\section{Locating, Analyzing and Making Available a Century of 4-H Research Studies, 1911-2011}

Jan Scholl and Amy Paster

Penn State University

\begin{abstract}
For years, $4-\mathrm{H}$ has emphasized the value of being a research-based youth organization in its long term association with the land-grant university system. But, it was the general consensus among state and national leaders that the program had no research base. The main objectives of this study were to: locate and document research studies conducted (between 1911-2010) in order to support or dispel notions about the lack of $4-\mathrm{H}$ research and its focus on cows and cooking, to make information about the research studies available to the larger community of youth program practitioners and researchers and provide a general review of research topics by decade. Three thousand five hundred and fifty six studies were found over a thirteen year period and only one percent of these related to "cows or cooking." To make the data available to current and future youth professionals and researchers, the information about each study was transferred to an Internet web-site. Finally, a full century of research topics were summarized.
\end{abstract}

\section{Need for the Study}

The role of research within many nonprofit youth organizations has experienced a steep rise in importance (Bialeschki \& Conn, 2011). Research data are pivotal when: "...documenting issues, [providing] potential solutions to problems, and [acquiring the] resources needed to make the necessary changes to meet ever-changing demands in working with youth" (p. 301).

For years, the Cooperative Extension Service has made the case for research-based programs through its association with the United States Department of Agriculture (USDA), the university land-grant system and county governments. (4- $\mathrm{H}$, a Cooperative Extension program was originally created to serve the needs of youth, eight to 18 years old). Despite this goal, many youth professionals and administrators have argued that this research did not exist. 
In 1986 the Executive Director of the National 4-H Council, Don Stormer, reported that the 4-H research base was insufficient (lack of quantity) to ensure the program's "future viability" ( $p$. 16). George McDowell (2001), author of the book Land-Grant Universities and Extension into the $21^{\text {st }}$ Century, agreed: "We always knew more about the cows [and cooking] than the kids" (p. 156). As recently as 2011, a team from Seattle Pacific University found that Extension educators did not know where to find the 4-H studies and found it too time consuming to acquire and utilize this research (Bikos, et al.). These perceptions have resulted in such serious consequences, as: a lack of status among other Extension Service programs, development officers refusing to seek funds for the program, and the inability of practitioners and researchers to utilize studies to develop quality programs and support future research.

\section{Objectives of the Study}

The main objectives of this study were to: 1) locate and document all research studies conducted about the 4-H program and support or dispel the notion about the lack of research; 2) support or dispel McDowell's statement that the majority of 4- $\mathrm{H}$ research studies focus on livestock and food preparation; (3) make information about the research studies available to the larger community of youth program practitioners and researchers; and (4) provide a general review of a century of research topics by decade.

\section{Review of Literature}

Though 4-H is currently conducted in every state, and in urban as well as rural areas, the foundation of the program was practical education and its application to the vocations of farming and homemaking. 4-H clubs met outside of school, even when their leaders were school superintendents.

There is evidence that the 4-H program was based on educational theory. According to William Beardshear (National Education Association, 1902), president of Iowa State College, the notion of $3 \mathrm{Hs}$ (head, heart and hands) was as significant among educators as the 3Rs: reading, 'riting, and 'rithmetic. Beardshear explained that the $3 \mathrm{Hs}$ were based on the work of Ferdinand Edouard Bussion, a nineteenth century French educator (who later received a Nobel Prize).

O.H. Benson (1915) added the fourth $\mathrm{H}$ to satisfy a four-square model of education, but references to the $3 \mathrm{Hs}$ continued in literature and were adopted by educational organizations throughout the twentieth century. Notably, Rudyard Kipling (1906) included the 3Hs at the end of his poem about childhood and later, Benjamin Bloom (1956) reissued the $3 \mathrm{Hs}$ as educational objectives: cognitive (head), affective (heart), and psychomotor (hands). The $3 \mathrm{Hs}$ were also included in school songs (Sutphin and Hillison, 1999).

Few studies compared the goals and operations of early youth groups (Page, 1919). Some of the earliest youth development studies were conducted by G. Stanley Hall of Clark University, who is credited with the term "adolescence." His students made several contributions: Harston (1911) studied the psychology of clubs, Pleasant (1914) investigated organizations for boys, and Swift (1914) wrote Learning and Doing, the basis for the 4-H slogan, "Learn by Doing."

The clubs in these early studies might be listed for the reader, except that their programs no longer exist. The first studies of youth service organizations, that included 4-H, Girl and Boy Scouts, and Camp Fire among other national organizations, were published by Page (1919) and the Associated Youth Serving Organizations in 1944. 
With 4-H's exceptionally strong connection with land-grant colleges and universities throughout the country, it would seem logical that the research mission of these institutions would reflect the work and study of its youth professionals. Scholl and Munuya (2004) hypothesized that 4-H studies were not well known because their findings were reported in many types of publications: graduate work, government documents, reports of polling organizations, such as Gallup (1979), as well as in peer-reviewed research journals. They also predicted that as technology advanced, it would be possible to locate and document most if not all of this research and determine whether perceptions about any lack of research were justified. Once it was realized that the first known studies were published in 1911, it became a challenge to document and describe the program's century of research studies.

\section{Methods and Findings Related to the Objectives}

In many research studies, the methods for each objective are reported together; likewise for the findings. Because methods used in this study vary, the methods and findings for each objective are reported together in order to aid the reader. The limitations, definitions and explanations for this study are included under Objective 1.

\section{Objective 1: To locate and document all research studies conducted about the 4-H program and support or dispel the notion about the lack of research.}

\section{Objective 1: Methods}

In order to find and document the 4-H research studies it was important to develop a plan. Most of the studies were located by five different means:

1) review materials in the stacks (in this case the restricted areas of the library where documents are stored) and card catalogs of the National Agricultural Library and the National Archives (Archives II, College Park, MD),

2) review department libraries at eight institutions which do not catalog master's degree studies in their university libraries,

3) conduct an initial call for research studies among the state leaders of the 4-H program and send monthly listserv e-mails to $4-\mathrm{H}$ youth professionals with the assistance of the National 4-H Headquarters,

4) scan library and Internet web-sites to find other sources, and

5) review reference lists in order to find additional studies.

USAIN (U.S. Agricultural Information Network) and Canadian librarians were also contacted to locate U.S. and international library holdings. Special collections in library archives throughout the country were also studied.

When there were questions about the study's relevance to the 4-H program, a copy was borrowed or purchased and then reviewed. In some cases, it was also necessary to contact the registrar of a college or university to obtain additional information.

Information about the studies was placed and sorted on two databases, one for graduate student studies and another for state, national and government (professional) studies. This information included: author, title, college or university, type of publication, date of publication or graduation, degree (if any), and the abstract. A Filemaker Pro ${ }^{\mathrm{TM}}$ (1994) software was used to store and sort studies as they were found. 


\section{Limitations, Definitions and Explanations}

- The main purpose of this study was to locate and document 4-H research studies completed between 1911 and 2010. Though some professionals refer to a research base as a "research methods base" that has been mined for research methods, theory and/or findings, for the purpose of this study, a research base was defined as the body of research conducted about the 4-H program. No attempt was made to determine the quality of each study. Reviewers looked at the methodology, but it wasn't possible to generalize except to say the authors of these studies used and modified a variety of models, theories, and descriptive, co-relational and quasi-experimental methods in order to reach their objectives. It was felt it would be a greater contribution to provide the research study data on-line and allow youth practitioners and researchers to make their own determinations as to the value of the research methods. (See Objective 3.)

- Some may question why graduate studies were investigated. It was known before the study started that many of these student researchers were 4- $\mathrm{H}$ youth professionals with aspirations to further their programs and make a contribution to the larger organization. Many of these student researchers became state and national 4-H leaders. More than a few of these studies led to additional investigations and program innovation during their careers.

- While it is entirely possible that not all of the 4-H studies were found, thirteen years (1998 through the first half of 2011) were actively dedicated to this effort.

\section{Objective 1: Findings}

The location of 4-H studies was difficult. "4- $\mathrm{H}$ " and " $4 \mathrm{H}$ " appeared as part of dozens of chemical compounds frequently studied by scientists in a variety of fields. The "4- $\mathrm{H}$ " found in a

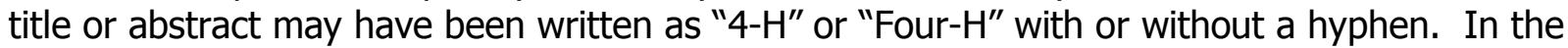
early years, the program was known as boys and girls clubs, $3-\mathrm{H}$, junior clubs and even industrial clubs. Depending on the country, the 4-H program was recognized as: 4-A, 4-B, 4-C, $5-\mathrm{C}, 4-\mathrm{K}, 4-\mathrm{S}$, or 4-T or a title in any number of languages. In addition, many of the colleges represented by the studies became universities and several experienced dramatic name changes: Glassboro College to Rowan University, for example.

The location, coding and sorting of studies as indicated in the methods section for Objective 1 yielded the following information:

- Over 3550 (3556) studies were found representing the years 1911 through 2010.

- 2251 were graduate student studies and 1305 professional studies, roughly a two-toone ratio. During World War II and the decade of the 2000s, the numbers of graduate and professional studies were nearly the same.

- Of the graduate studies, nearly $75 \%$ were conducted by students completing a master's degree and 25\% were those completing doctorates, including Ph.D. and Ed.D. degrees. Bachelor's degree, certificate, diploma and license-related studies were reviewed, but these represented less than one percent of the studies.

- Graduate Studies represented 150 colleges across the U.S., Canada and a handful of countries and territories. Most of the studies originated from land-grant institutions, but there were also studies from: Harvard, the University of Chicago and lesser known institutions, such as the Stonier Graduate School of Banking and the National Catholic School of Social Sciences. 
- Graduate Studies: These studies represented a wide variety of academic departments, including: Economics, English, Law, and Recreation, for example, as well as Education, Agriculture and Home Economics/Family and Consumer Sciences.

- Graduate Studies: Those institutions graduating the most students at all locations were: the University of Wisconsin (160 studies), Ohio State University (153 studies), the University of Maryland (115 studies) and Penn State University (94 studies). In the South, Louisiana State University (94 studies) and the University of Tennessee (89 studies) matriculated by far the largest number. Fifty institutions produced just one study.

- Professional Studies: The professional studies (including state, national and government studies) represented institutions similar to those listed above. In addition, at least ten percent were studies published by the: USDA, National 4-H Council, Extension Committee on Organization and Policy (ECOP), and colleges and universities in the Washington, D.C. area: American University, George Washington University and Federal City College. Twenty percent were multi-state and regional studies.

- Professional Studies: Independent studies were conducted by Abt Associate (Shapiro, 1974), the Department of Health, Education and Welfare (Hoyt, 1978), the Science and Education Administration (Scriven, 1979), the Gallup Organization (1979), the Social Research Group (Dennis \& Hurt, 1979), Nike Whitcome Associates (Chicago, 1989), and the Human Interaction Research Institute (Backer \& Kunz, 2002).

- International Studies: Though 4-H began in the U.S., it is an international organization. Studies were found from: Canada, Greece, Guatemala, Iran and the West Indies.

- All studies: Thirty-six studies were specifically identified with both 4-H and FFA (Future Farmers of America). Two studies described or compared 4-H with FHA (Future Homemakers of America now called, Family, Career and Community Leaders of America (FCCLA); two studies with Camp Fire youth. Six studies related to scouting. Most of these studies addressed community aspects of youth organizations and focused on joint efforts to prevent juvenile delinquency.

- The distribution of all of the studies found are reported by decade in the following chart: graduate student and professional studies are plotted separately. 
Figure 1

\section{4-H Research Studies \\ 1911 - 2011 \\ By Decade}

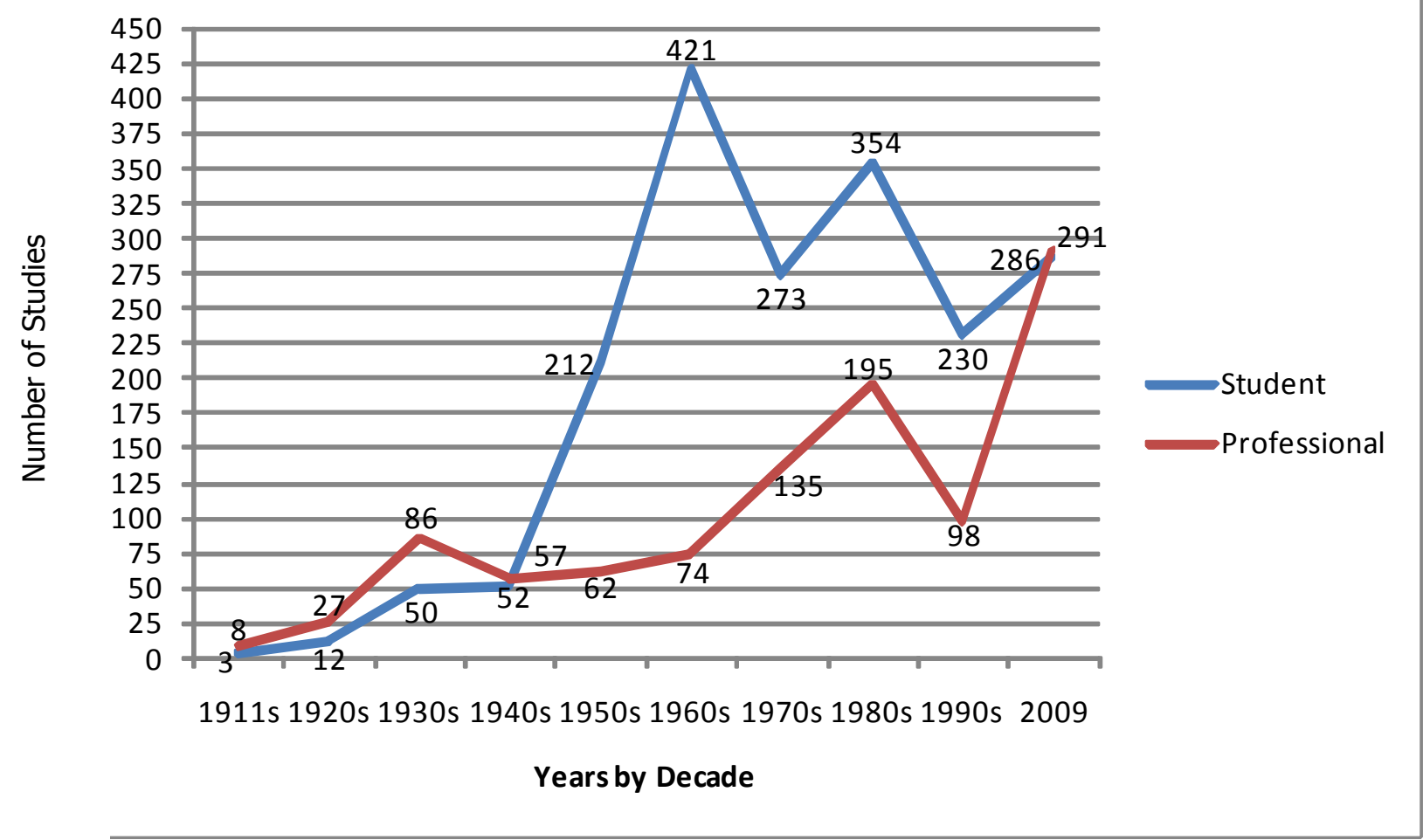

The chart in Figure 1 shows a surge in graduate studies in the 1960s, perhaps because the Payne/4-H Fellowships Fund (Copeland \& McAuliffe, 2008), continued to increase the number of graduate study scholarships given until 1969 . The quantity of graduate and professional studies was approximately the same during World War II and in the 2000s when more studies were published in refereed journals. The main increases in professional studies in the 2000s occurred during 2005 and 2007.

The research team determined from these findings that there was a large body of research studies created by both graduate students and professionals to provide a basis for further documentation and study. Though no specific research agenda was found in this literature, it is interesting to note that, starting in 1952, at least twenty studies were completed every year.

\section{Objective 2: To support or dispel McDowell's statement that the majority of 4-H research studies focused on livestock or cooking.}

\section{Objective 2: Methods}

A qualitative research approach was applied in the analysis of the content of the 3556 studies to address McDowell's statement. The procedures used were based on Berg (2004), Berg and Latin (2004), and the criteria for analyzing documents, provided by Creswell (2009, p. 180).

In many qualitative studies, the focus is on identifying themes and gaining insight in order to make decisions or establish policy. The data set is studied until content themes begin to repeat themselves. 
In this study, content analysis was used rather than establishing statistical significance or extrapolating findings from a random sample to larger populations (both typical in quantitative studies). The research team applied this technique and reviewed the content in all of the studies.

As recommended by Gibbs (2007), independent coders entered and made comparisons in order to improve the validity and reliability of the data and the findings. The databases allowed topics to be sorted and studied by content and keyword search. A cross-tabulation analysis was also employed where two or more topics, related to a theme or research question, were addressed within a single study.

\section{Objective 2: Findings}

Less than $1 \%$ of the 3556 studies referred to any type of livestock, cooking, or foods and nutrition project. In fact, less than five percent of the studies could be connected to any type of 4-H project. Though the reviewers utilized online as well as hand-sorting methods, it was extremely difficult to quantify the research topics as the individual studies often addressed five or more factors.

The reviewers sorted the remaining studies into 32 categories (33 if curriculum is counted) not so much for the purpose of generalizing the studies or indicating their importance, but to create a thesaurus with keywords so others could locate the research studies on-line. (See Objective 3.) The alphabetical listing of the main category headings were: 1) adults (volunteers, alumni, mentors), 2) agents (4-H educators), 3) careers (4-H participant related), 4) children, 5) community, 6) competition, 7) conferences, 8) cooperation among agencies, 9) cooperation among extension employees, 10) curriculum, 11) disadvantaged youth (low income, children of offenders, vulnerable youth), 12) diversity (including disability), 13) economics (organizational), 14) educational concepts, 15) events and fairs, 16) history, 17) home demonstration clubs, 18) international/cultural, 19) leaders and leadership, 20) meetings (types), 21) new audiences, 22) older youth (teens and those older than eighteen), 23) organizational policies, 24) promotion, 25) public speaking, 26) school and after school programs, 27) research methods, 28) science, 29) tenure and enrollment, 30) technology and media, 31) values, and 32) youth input. An additional category was added and called "comparisons," which included studies that paired perceptions of adults vs. youth, administrators vs. practitioners, legislators vs. administrations, etc.

\section{Objective 3: Make information about the research studies available to the larger community of youth program practitioners and researchers.}

\section{Objective 3: Methods}

In 2007, the studies on the Filemaker Pro ${ }^{\mathrm{TM}}$ (1994) software were transferred onto an Internet web-site by the Penn State University (Paterno) Library and AgNIC (Agriculture Network Information Center) to make the research information available to the public. The Internet site was designed so that new studies could be continuously added and users could locate studies by author, title, date or keyword. One database housed the graduate studies; another, the professional studies. An option was designed to allow users to sort their list of studies into an alphabetical bibliography. A web-site "counter" was created so that the location and type of users could be noted. A "contact us" feature was established so users could ask questions and receive assistance. 


\section{Objective 3: Findings}

The web-site was developed in 2007 and revised (in 2009 and 2011) by an outside consultant and a team of information technology experts at the Penn State University (Paterno) and the National Agricultural Libraries in 2010-2011. The counter feature indicated users represented the fifty states and Canada and those that accessed the site, included: researchers (both professional and graduate students), youth professionals (in 4-H and other groups), administrators of Extension and other programs, legislators, parents and the youth. The URLS to find the 4-H research databases changed several times during the process of completion and, regulated by the library systems, became complex. A printed bookmark, with the URL: http://apps.libraries.psu.edu/agnic, was widely distributed at conferences and 4-H leader forums. Many other users found their way to the site by entering "4-H research" in a search engine browser.

\section{Objective 4: To provide a general review of a century of research topics by decade}

\section{Objective 4: Methods}

The research team determined the following review of research topics and trends using the methods outlined for Objective 2, including an online keyword search and hand sort of studies. A few representative studies for each decade were determined and included within the text to give the readers concrete examples.

\section{Objective 4: Findings \\ 1910s.}

The first studies were published in 1911 by Harston, who described boys and girls clubs (what 4-H programs were called in the early years), and Jessie Field Shambaugh (1911) who conducted agricultural experiments with 3-H youngsters in her school district. Pauline Raven (1913), Montana State College (1914) and later, Shinn (1928) looked at the Extension programs which resulted from early 4-H work and their value to home and farm life. Danzinger (1918) investigated and made recommendations for fair exhibits at the county, state and regional levels.

\section{0s.}

Throughout the century, there were a surprisingly few studies on the value of giving demonstrations and public speaking. During the early years, demonstrations referred to the progress young people made in a project, such as a test plot or a home or garden improvement. They were rarely "how-to" presentations given in front of group.

In 1924, the first camping study was conducted by the Eastern States Exposition at Camp Vail in Massachusetts. Leadership and character building were first studied in 1926. (Studies relating to the development of leadership appeared almost every year between 1926 and 2010).

The national club camp was evaluated by USDA in 1927 and, during this landmark event, the 4-H pledge was determined and a formal 4-H uniform was required though the young people lived and slept in tents on the Capital Mall in Washington, DC.

By the end of the 1920s, project requirements were investigated by Reese (1929) and his team. Wiley (1928) and Wenzel (1930) studied the value of socialization within clubs.

\section{0s.}


By 1931, former members were surveyed, by Grady, and a "future outlook" projected. Researchers began to look at the length of 4-H membership and determine why members did or did not reenroll.

In the early 1930s, youth income, educational values and college aspirations were prominent topics. Attendance at college was emphasized and young people earned funds by raising cattle and canning foods. Cooperative Houses on campuses kept their expenses low (Smith, 1941). Part of this may have been an attempt to support the values of farm life (as so many were leaving the farms to live in the city) by providing educational and social activities. In any case, these programs were prominent through the 1960s. The Extension Service was also concerned about non-college bound youth between 18 and 21 years of age (Barnard \& Crile, 1940).

\section{0s.}

In the 1940s, 1950s and 1960s, enrollment studies were evident. Researchers were interested in what could be done to market 4-H and keep members enrolled, especially after their first year of enrollment and during their teen years. Programs for Black youth were now being developed and studied. This was the first time record books were looked at in any analytical way (Palmer, 1940). Between 1941 and 1942, Frutchey and eight other collaborators published a half dozen "educational growth studies" in 4-H food preservation, clothing, dairy, cotton, and sheep, starting with vegetable gardening (1941). In 1942, Peroutky studied livestock evaluation using a "systems approach." The forties was also a time when the needs of youth were reviewed both during and after World War II. Junior leadership programs were also coming into their own.

\section{0s.}

In the 1950 s, ways were being developed to determine how 4-H professionals spent their time. Increasing the effectiveness of $4-\mathrm{H}$ in-services and leadership programs, project completions, judging and award systems were efforts to prevent loss of membership and bolster motivation and personal development.

The impact of television and data from the International Farm Youth Exchanges (exchanges to other countries) were analyzed in 1954-56. Programs for low socioeconomic, disadvantaged, and non-farm families were considered in order to meet the needs of these youth.

News stories, bulletins and circular letters were also analyzed and two studies inquired whether certain types of illustrations could improve project books (Wilkening, Clark \& Landry, 1956; Taylor, 1960).

In the 1950 s and $1960 \mathrm{~s}$, researchers tried to determine whether $4-\mathrm{H}$ made a difference in the personal/social development and academic achievement of youth or if too much time was being spent away from school and other activities. Citizenship activities were piloted in five states in 1962 and the National 4-H Club Foundation (1963) proposed expanding the curricula to include science, a topic which up to that time was taught only in school.

\section{0s.}

First year club leaders were targeted in 1963 and 1964 in order to help them improve their experiences and the viability of their clubs. In 1964, urban areas were studied and youth became involved in 4-H Peace Corps projects (Schmidt). One study determined that the continuance factor in volunteer leadership was not necessarily an organizational issue but largely a matter of personal orientation (Brog \& Couch, 1965). 
Photography, clothing selection and home furnishing projects were studied in the latter part of the 1960s. Innovative programs and educational games were evaluated. There was a renewed interest in leadership programs and in successful club meetings.

\section{0s.}

By the end of the 1960s and the beginning of the 1970s, studies of low-income volunteers, minorities, and urban and inner-city programs were prominent. Critical components of the 4-H professional's job, use of volunteers and newly hired paraprofessionals, and staffing models were analyzed. Educational club programs on television were investigated, especially the Mulligan Stew series (Shapiro, 1974) designed to teach nutrition concepts. Cooperative Extension was becoming more and more aware of children's food choices and the Expanded Foods and Nutrition Program (EFNEP) was established to address (and still addresses) the needs of low-income youth and adults. 4-H foundations were first studied in the $1960 \mathrm{~s}$ and 1970 s to help secure funds for expanding programs.

In 1975, programs for disabled or underserved youth were reviewed in an effort to be more inclusive. Awards as incentives were studied. Internships and fellowships became more prominent and the curriculum development focus was more practical. In 1978, intergenerational projects came into vogue and were studied by Minnich. Audio cassettes were the latest in educational technology (Mortvedt \& Fain, 1978). The relationship of 4-H and the schools was renewed and there were a few studies on what youth gained from animal/livestock programs.

The national Citizenship Washington Focus (conference) participants were surveyed by Johnson (1979) as the old Citizenship Short Course was being revamped. Researchers looked at: middle management, economics, developmental and interactional theories, future trends, and consequences of negative social behaviors.

\section{0s.}

In 1980, there was a historical bent to the research: a longitudinal look at youth programs between 1948 and 1980 and studies about national camps and conferences over 50 years. Teen friendship patterns (Beasley, Conner \& Ostrander, 1980) were examined with implications for recruitment and programming in the $4-\mathrm{H}$ program.

Partnerships with the American Red Cross, the Defense Department and other groups were reviewed as well as the 4-H professional association, NAE4-HA. Complex financial and public relationships of Extension Service were in question as well as 4-H's impact on groups such as the Extension homemakers, livestock producers and 4- $\mathrm{H}$ alumni. Time and money spent by adult volunteer leaders were also studied.

Teen alcohol use, family strengths, and psychosocial maturity were prominent issues among 4- $\mathrm{H}$ and non-4- $\mathrm{H}$ youth in 1981. The awards system, including an evaluation of the national awards system, was reviewed. In 1983, USDA published an analysis and recommendations of a national 4-H needs assessment. Computer projects for youth were pilot tested (by Maurer) in 1984.

Criteria and quality indicators for relevant 4-H curriculum development were developed, and some career development strategies addressed (Hoyt, 1978). Leadership styles and life skills were coming to the forefront and $4-\mathrm{H}$ was concerned with strengthening the research base for 
Extension programs. A national research taxonomy, PRK (Professional Research and Knowledge) was established (Lifer \& Gerhard, 1987). In the late 1980s, there was a resurgence of studies related to: curriculum, science, school programs, dropouts, volunteers and staffing models, awards and benefits to alumni. Barber (1988) also studied the ethical dilemmas 4-H professionals encountered in their work.

1990s.

Barriers to "youth-at-risk" programs were an issue in the 1990s. More focus was given to the job satisfaction of 4-H professionals and improvements in their family life. Factors related to curriculum, international work, strengthening youth-serving and community organizations, youth with disabilities, and fair exhibits were by far the most studied topics during this time period.

Parents were surveyed giving their perceptions of the value of the 4-H program. Mentoring, learning styles, life skills, workforce education (occupational analysis), and sportsmanship studies were prominent. Community Service became "service learning" and articles on diversity education were published. The tenure status of volunteers and faculty was studied. The practical applications of technology were investigated in order to solve organizational problems, such as: answering questions about 4- $\mathrm{H}$ events and developing curriculum. This continued in the 2000s, as retinal imaging was used to identify project animals (Rusk, et al., 2006; Howell, et al., 2008).

In the late 1990s and 2000, teens were utilized in team teaching and as cooperating researchers. The educational value of $4-\mathrm{H}$ activities was reviewed. Several theoretical models were proposed. Life skill and core competency studies focused on what youth gained from both the project and the interactive experiences. Alcohol and drug education, civic engagement and camping studies remained strong.

\section{0s.}

In the 2000s, the research studies were as diverse as ever. In 2002, the Story of 4-H's National Conversation on Youth Development in the $21^{\text {st }}$ Century was published (Backer \& Kunz) and perceptions held by legislators were analyzed (Hodson, \& Kotrlik, 2002). Environmental literacy and after-school programs were now being conducted; preferred forms of recognition and motivations reviewed. Though some researchers felt that 4-H should move away from record book requirements; other studies emphasized their value.

In 2005, the first public speaking study appeared (Donaldson et. al) and the first 4-H study addressing a science program was targeted to girls (Speigel et al.). In 2006, 2007, and 2008, robotics was evaluated as a project option. In 2009 and 2010, social networking was considered as a marketing and program enhancer. Programs for military youth were created and investigated in the late 2000s.

\section{Conclusions and Implications}

The primary objectives of this study were to: locate and document all existing research studies conducted about the 4-H program, to support or dispel notions about the lack of research and its focus on livestock and cooking. Other related goals were to make information about the research studies available to the larger community of youth program practitioners and researchers, and finally, to provide a general review of research topics by decade. 
A large body of research about the 4-H program was found. Only a few studies related to livestock, cooking or 4-H projects in general. Technology aided greatly in the location of studies, the analysis, and making the information directly available to users. As information about newly published 4-H studies is continuously added to the databases and made available to youth professionals and researchers, the forecast for future study is bright.

In 2011, Bialeschki and Conn recognized the authors of this paper as representing one of the few youth serving organization that attempted to locate all of their research studies in a format that may be studied. While it was not within this study's scope to support or refute this, the study does provide a model to find research published in a variety of documents, not only for the purpose of creating reviews of literature, but to document a body of research conducted over a long period of time. Once this is done, it becomes possible to establish an agenda with objectives that can be communicated to encourage future research, document issues, provide potential solutions to problems, and acquire the resources needed to continue and improve youth development efforts. Longitudinal studies can be proposed. Studies of critical need can be conducted on a regular basis and their results compared from year to year or decade to decade. Studies can be built on exploratory efforts and replicated in many places. Funding agencies, legislators, administrators and youth practitioners can obtain the information they need to make decisions that benefit program planning and implementation.

In terms of future research, some may wish to investigate one or more of the thirty-three categories of research themes found in this study. Likely these categories will be of interest to other youth-serving organizations with similar concerns and research agendas. Another major contribution might be to document the overall value of the 4- $\mathrm{H}$ program as nearly every study addressed this issue in some way.

Though there may be many additional studies conducted and further research collaborations established, at the beginning of this study few, if any, practitioners and administrators could even imagine that 4-H research studies had been conducted for 100 years. If nothing else has been accomplished, at least the youth practitioners in this organization will now know that a large body of study supports their efforts.

\section{References}

Associated Youth Serving Organizations. (1944). The Associated Youth Serving Organizations, Inc. announces the completion of its organization. New York: Author.

Backer, T., \& Kunz, C. (2002). Creating the future: The story of the 4-H's national conversations on youth development in the $21^{\text {st }}$ century. Washington, DC: National 4-H Council.

Barnard, J., \& Crile, L. (1940). 4-H and older youth studies: Some findings, bibliography, and studies in progress. Washington, DC: USDA Extension Service.

Barber, S. (1988). Ethical value dilemmas of 4-H professionals in the Cooperative Extension system. National Agricultural Library LB1779.B32.

Beasley, J., Conner, N., \& Ostrander, R. (1980, September/October). Teen friendship patterns: Implications for 4-H recruitment and programming, Journal of Extension, 30. 
Benson, O.H. (1915). School credit for boys and girls club work and Extension activities in agriculture and home economics. Proceedings of the National Education Association Annual Meeting.

Berg, B. (2004, $5^{\text {th }}$ edition). Qualitative research methods for the social sciences. Boston, MA: Allyn and Bacon.

Berg, K., \& Latin, R. (2004, $2^{\text {nd }}$ edition). Essentials of research methods in health, physical education, exercise science, and recreation. Philadelphia: Lippincott, Williams and Wilkins.

Bialeschki, M., \& Conn, M. (2011). Welcome to our world: Bridging youth development research in nonprofit and academic communities. Journal of Adolescence, 21(1), 300306.

Bikos, L., et al. (2011). Investigation the utilization of research evidence in the 4-H youth development program. Journal of Youth Development, 6(2), 15 pp. Article 110602FA002, http://data.memberclicks.com/site/nae4a/JYDfinal0602.pdf

Bloom, B. (1956). Taxonomy of educational objectives: The classification of educational goals. New York, NY: Longmans, Green.

Brog, G., \& Couch, C. (1965). Self-confidence and tenure: Continuance or discontinuance of the leader role is largely a matter of personal orientation. Journal of Extension, 3(2), 110-112.

Copeland, H., \& McAuliffe, V. (2008). Windows to a wider world: The Payne/National 4-H Fellowships, 1931-1969. Saint Paul, MN: Payne/National 4-H Fellowships Alumni.

Creswell, J. (2009, $3^{\text {rd }}$ edition). Research design: Qualitative, quantitative, and mixed methods approaches. Los Angeles, CA: SAGE Publications.

Danzinger, M. (1918). Suggestions for boys and girls exhibits (at local, county and state fairs). Washington, DC: Government Printing Office.

Dennis, D., \& Hurt, M. (1979). Youth in America: A social indicators chart book of the 4-H eligible population. Washington, DC: George Washington University, Social Research Group.

Donaldson, J., Martz, Jl, Ezell, P., Stewart, J., Beaty, M., \& Bullington, D. (2005). Developing a scale to measure public speaking skills achieved by $4-\mathrm{H}$ youth. Proceedings of the National Association of Extension 4-H Agents Annual Meeting, p. 21.

Eastern States Exposition (1924). Boys and girls club work in agriculture and home economics...1924, 1926-1927, and 1931. Springfield, MA: Camp Vail.

Filemaker Pro 4.0 ${ }^{\mathrm{TM}}$ (1994). Filemaker Pro, Inc. [Filemaker is a data management software. It may be purchased from FileMaker, Inc., 5201 Patrick Henry Drive, Santa Clara, CA 95054. This particular version of the software made it easy for our team both to sort and later, to transfer it to the Internet.] 
Frutchey, R., Nodine, E., Erickson, G. (1941). Evaluation in the 4-H vegetable garden project., Massachusetts, 1939. USDA, Extension Service (ES) Circular 353. 27 pp.

Gallup Organization. (1979). The Gallup study of adults' and children's participation in 4-H youth programs. Report. Princeton, NJ: Author.

Gibbs, G. (2007). Analyzing qualitative data. Los Angeles, CA: SAGE Publications.

Grady, R. (1931). A study of former 4-H club members in Hancock County, Maine. [Published in the annual report of a county agent].

Hartson, L. (1911). The psychology of the club. Unpublished doctoral dissertation, Clark University, Worchester, MA. [Also published in the 1911 issue of the journal, Pedagogical Summary].

Hodson, P., \& Kotrlik, J. (2002). Perceptions held by legislators toward the Louisiana Cooperative Extension Service, Journal of Agricultural Education, 43(4), 56-66.

Hoyt, K. (1978). Monographs on career education: 4-H and career education. Washington, DC: Department of Health, Education and Welfare.

Howell, B., Rusk, C., Blomeke, C., McKee, R., \& Lemenager, R. (2008). Perceptions of Retinal Imaging Technology for Verifying the Identity of 4-H Ruminant Animals. Journal of Extension, 46(5),online. http://www.joe.org/joe/2008october/rb9.php

Johnson, B. (1979). A comparative study of Citizenship Washington Focus participants: Trends and recommendations. Washington, DC: National 4-H Council.

Kipling, R. (1906). The children's song (poem). In Puck of Pooks Hill, Garden City, NY: Doubleday. Retrieved from: http://www.enginesofmischief.com/makers/evan/poetry/ childrens.html.

Lifer, C., \& Gerhard, C. (1987). A taxonomy of the knowledge base for the 4-H Youth Development Education, Phase 1. Washington, DC: Cooperative Extension System.

Maurer, R. (1984). 4-H computer project: National pilot test evaluation: Final report. Lexington, KY: University of Kentucky.

McDowell, G. (2001). Land Grant Universities and Extension into the $21^{\text {st }}$ Century: Renegotiating or abandoning a social contract. Ames, IA: Iowa State University Press.

Minnich, B. (1978). 4-H intergenerations project: Final intern report. College Park, MD: Archives II, Special Collection, Box 27.

Montana State College (1914). What club work is doing for Montana farm and home life (circular). Bozeman, MT: Montana Cooperative Extension Service.

Mortvedt, M., \& Fain, S. (1978). An evaluation of the audio-cassette series, "The 4-H Volunteer Community." Columbus, $\mathrm{OH}$ : Ohio State University. 
National Education Association. (1902). Journal of Proceedings and Addresses of the 41st Annual Meeting 1902. Minneapolis, MN: Author.

National 4-H Club Foundation (1963). A study of the possibilities of expanding the understanding and use of science through 4-H club work. Chicago, IL: Author.

Nike Whitcome Associates, Inc. (1989). A feasibility study for Missouri 4-H Foundation. Chicago, IL: Author.

Page, J.F. (1919). Socializing for the new order: Educational values of the juvenile organization, including a resume of Boy Scouts, Camp Fire Girls and twe/ve other organizations. Rock Island, IL: Author.

Palmer, W.H. (1940). The 4-H members book: 4-H members records from 17 states were checked against 15 criteria. Columbus, $\mathrm{OH}$, Ohio Agricultural College (circular).

Peroutky, V. (1942). A systems approach to developing and evaluating 4-H youth livestock projects. Moscow, ID: University of Idaho.

Pleasant, G. (1914). Organizations for boys and their educational value. Masters of Arts thesis, Clark University.

Raven, P. (1913). Extension work in home economics in normal schools. Masters of Home Economics thesis, Michigan State College.

Reese, M. (1929). Compilation of findings of the committee on project requirements reported at the 1929 National Farm Boys' and Girls' 4-H Club Camp. Washington, DC: USDA, Ag Extension Service Stencil No. 5384.

Rusk, C., Blomeke, C., Balschweid, M., Elliott, S. \& Baker, D. (2006). An evaluation of retinal imaging technology for 4-H beef and sheep identification. Journal of Extension, 44(5), on-line. http://www.joe.org/joe/2006october/a7.php

Schmidt, W. (1964). Evaluation of training for 4-H Peace Corps projects. Chicago, IL: National 4-H Foundation.

Scholl, J., \& Munyua, C. (2004, October). Establishing a research base for the 4-H program. Journal of Extension, 42(5) Feature Article 5FEA7, http://www.joe.org/joe/2004 october/a7.php.

Scriven, M. (1979). High potential consequences of the 4-H program. Washington, DC: Science and Education Administration. Located in the National Agricultural Library: MLCM 83/988.

Shambaugh, J. (1911). The corn lady: The story of a country teacher's work. Chicago, IL: A Flanagan Co.

Shapiro, S. (1974). An evaluation of Mulligan Stew TV (television) series. Cambridge, MA: Abt Associates. 
Shinn, E.H. (1928). Objectives in a program of rural life improvement. Washington, DC: Extension Service Circular 80.

Smith, R. (1941). Cooperative 4-H houses on college campuses. Washington, DC: USDA, Misc. Extension Publication No. 57.

Speigel, A., Rockwell, S., Acklie, D., Frerichs, S., French, K., \& Diamond, J. (2005). Wonderwise 4-H: Following in the footsteps of women scientists. Journal of Extension, 43(4), Article No. 4FEA3, on-line.

Stormer, D. (1986, May). Research base for Extension programs. News and Views, 16.

Sutphin, C., \& Hillison, J. (1999). History of Extension work in Virginia prior to Smith-Lever [Act]. Journal of Extension, 376), http://www.joe.org/joe/1999december/comm2.php

Swift, E. (1914).Learning and doing. Indianapolis, IN: Bobbs-Merrill Company.

Taylor, L. (1960). An evaluation of 4-H bulletin 197, 4-H vegetable garden. [The only known copy is in the National Agricultural Library, call number: MLCM 83/43].

USDA. (1927). Outline for findings of the standardization committee appointed at the 1927 National Farm Boys and Girls 4-H Club Camp. Washington, DC: Extension Service.

Wenzel, M. (1930). Boys and girls clubs as a social factor in North Dakota. Masters of Science thesis, North Dakota Agricultural College.

Wiley, H. (1928). The 4-H clubs as a factor in rural socialization. Masters of Science thesis, Michigan State College.

Wilkening, E., Clark, R., \& Landry, L. (1956). Effectiveness of a clothing handbook in teaching 4-H club members: $A$ study of the use of an illustrated handbook and other sources of help in the 4-H clothing project. Madison, WI: University of Wisconsin Experiment Station.

(C) Copyright of Journal of Youth Development $~$ Bridging Research and Practice. Content may not be copied or emailed to multiple sites or posted to a listserv without copyright holder's express written permission. However, users may print, download or email articles for individual use. 